\title{
A PREPARATORY STUDY OF CARE FOR ELDERLY WOMEN IN RURAL KENYA
}

KAORI AMP MIYACHI

Research Institute of Gender Equality, Saga University

kmiyachi@cc.saga-u.ac.jp

KEN MASUDA

School of Tropical Medicine and Clobal Health/School of Clobal Humanities and Social Science, Nagasaki University ken-m@nagasaki-u.ac.jp

Aвstract: Ageing is a global phenomenon, and sub-Saharan African countries will be no exception; however, no political framework for longterm care (LTC) for the elderly has been established as yet. Moreover, very little research on ageing has been carried out. Hence, the main purpose of this study is to illustrate the life of old women in Kwale County, Kenya, focusing on care. This study was conducted mainly in 2016 and 2017 for several weeks using basic information from the HDSS in Kwale, as well as interviews with 30 informants (elderly women) as the preparatory study for a future interdisciplinary research project on ageing. There are very few studies on aging or care for the elderly in Kenya. Some previous ethnographies have described old people in powerful positions and were focused on male issues. Therefore, we have focused on women and care. This study has yielded three key findings: (1) gender issues: most caregivers for old women are also women, such as daughters and daughters-in-law; (2) social change: some older females live alone without enough support from their own children; and (3) there is not enough medical support: 
some old women are bedridden and have serious health problems, but they do not receive special attention, compared to younger patients.

KEYwords: ageing; long-term care (LTC); old women; Kwale; Health Demographic Surveillance System (HDSS)

Resumen: El envejecimiento es un fenómeno mundial y los países del África subsahariana no son una excepción. Sin embargo, aún no se ha establecido el marco político de cuidados de larga duración (CLT) para las personas mayores; tampoco se han realizado muchas investigaciones sobre el envejecimiento. Por lo tanto, el propósito principal de este estudio es ilustrar la vida de las ancianas en el condado de Kwale, Kenia, centrándose en el cuidado. Este estudio se realizó durante algunas semanas de 2016 y 2017 utilizando información básica de HDSS en Kwale, y tuvo como informantes a 30 mujeres mayores con las que realizamos un estudio preparatorio para un futuro proyecto de investigación interdisciplinar sobre el envejecimiento . Los estudios sobre envejecimiento y cuidado de personas mayores son escasos en Kenia. Las etnografías anteriores describían a las personas mayores en una posición de poder y se centraban especialmente en los problemas de los hombres. Es por ello que esta investigación se centró en las mujeres y los problemas de atención. Esta investigación arrojó tres hallazgos clave: (1) cuestiones de género: la mayoría de los cuidadores de mujeres mayores son hijas y nueras; (2) cambio social: algunas mujeres mayores viven solas sin el apoyo suficiente de sus propios hijos; y (3) el apoyo médico es insuficiente: algunas mujeres están postradas en cama y tienen problemas de salud, pero los ancianos no reciben atención especial.

Palabras clave: envejecimiento; cuidados a largo plazo; ancianas; Kwale; Sistema de Vigilancia Demográfica de la Salud 


\section{Background}

Ageing is a global phenomenon that will eventually spread to sub-Saharan states. According to a World Health Organization (WHO) report (2015), between 2000 and 2050, the number of people over 60 years is expected to double worldwide. In addition, more than 1 in 5 individuals will be 60 or older by 2050 , and $80 \%$ of senior citizens will be living in low- and middle-income countries. There is a widespread notion that families take care of older parents in some African countries (WHO 2015).

In 2002, the United Nations (UN) adopted the Madrid International Plan of Action on Ageing, which stresses the importance of raising awareness and advocacy for a future ageing society (UN 2002). In Kenya, seniors (over 60 years old) comprise $3 \%$ of the population. It is predicted that this figure will be $13.5 \%$ in 2030 . Challenges ahead include the speed of ageing, which implies that there is not enough time to prepare for this time of life.

According to Cohen (2006) and Aboderin (2006), scholars have paid little attention to ageing in Africa and there are few studies on LTC. Cohen (2006) suggested researching ageing with respect to the following topics: 1) the household economy and income expenditure, 2) health and social welfare, 3) family support and networks, 4) public and non-public protections, and 5) HIV/AIDS. In addition, as UNFPA reported (2012), gender issues are also important in an ageing society, and affect quality of health, economic status, and safety. The international statistics show that women live longer than men, and that the unequal economic and social situation of women leads to the feminization of poverty.

At a WHO conference on ageing in sub-Saharan nations held in Nairobi in 2016, speakers warned that 'within sub-Saharan Africa, national efforts to develop LTC systems exist only in Mauritius, Seychelles, and South Africa' (WHO 2017). What are the current efforts being made in Kenya towards achieving LTC? The government of Kenya started making cash transfers for seniors (Old Persons Cash Transfer: OPCT) in 2007 in three pilot districts and it has gradually been expanded to cover low-income households as well (cf. Ikiara 2009). In 2018, as part of a program of the Ministry of Labour, Social Security and Services, the OPCT became an unconditional payment for all seniors over 70 as social protection. 
In addition to this government support, efforts from the private sector have been made to provide services for seniors in Nairobi. For example, a private nursing agency in Nairobi offers services in clients' homes regarding personal care, nutritional advice, psychosocial support, and disease management by the staff who are health professionals (nurses; physical, occupational, and speech therapists; counsellors; and physicians) (WHO 2017). There are also commercial activities, such as homes for the elderly, with medical care included. As for nongovernmental activities, there are several self-help groups supported by international organisations such as HelpAge International, which has been a prominent organisation that advocates for senior citizens' human rights. Some religious organisations also offer a place to sleep and food for old people who have been abandoned by their families and communities. But these private services are limited to people who can afford to pay for them and NGOs and religious support is only available partially and only in Nairobi and big cities. Nevertheless, in Nairobi, the situations are different in slums and according to gender perspectives (cf. Bennetta 2016, Cohen 2006, Mudege 2009). In a rural area, the care situation is still considered to be a family matter.

There are several studies in the field of gerontology and anthropology on the lives of old people in Africa, such as Habte-Gabr (1987), Fry (2000), De Medeiros (2013), and Buch (2015), and African ageing ethnographies are also described in Tagawa (2016) and Noguchi (2013). Matsuda (2000) also discussed care for the elderly in families in the western part of Kenya. However, sometimes issues regarding old people tend to describe male issues, such as magical and political power in communities. Gender issues are important in LTC (Ungerson 1987). As Miyachi (2017) stated, it is necessary to consider gender perspectives for future LTC matters. This is mainly because, for social and cultural reasons, women's economic and social status are not stable in rural areas, compared with that of men. The study was carried out in the coastal area of Kenya, Kwale, where international attention has been given to health. For example, Abubakar (2013) and Mochache (2020) discussed the attitude to health behaviours that are influenced by traditional beliefs in Digo and Mijikenda. Ethnic 
and religious attitudes also affect heath, which may also relate to LTC for families, for example how dementia is perceived in a community.

\section{Research Method}

This was the preliminary study before a much larger research project is conducted on ageing in the future. The authors of this article are social anthropologists, and have carried out research in different areas in Ethiopia (cf. Masuda 2009) and the west part of Kenya (cf. Miyachi 2014). The research was performed in a two-week period in March and April 2016, as well as a two-week period in August and September; another two-week period in September and October 2017; and during a brief visit to the key informants in 2018. The main questions included items about the household, as well as about relationships with family members (whether the interviewees lived with them or apart from them), physical and mental problems, care for seniors, and the circumstances related to the OPCT.

The main research methods included interviews and home visits with the participants (their ages spanned from 60 to centenarians) and mainly their families. The 30 interviewees included Muslim individuals who belonged to the Duruma and Digo peoples, as part of the Mijikenda ethnic group. It is common for women to move in with their husbands after marrying. Most of the interviewees were relatively healthy and received physical and financial support from their families.

The study was conducted in Kwale County, located in Kenya's coastal province (map 1) (map2). The Health Demographic Surveillance System (HDSS) is a database that registers births, deaths, and migration status etc., and covered almost 60,000 individuals (cf. Kaneko 2012, Sheru 2013) in 2010 in Kwale, including the areas of Kinango, Golini, and Mwaluphanba. 


\section{Map 1: Location of Kenya}

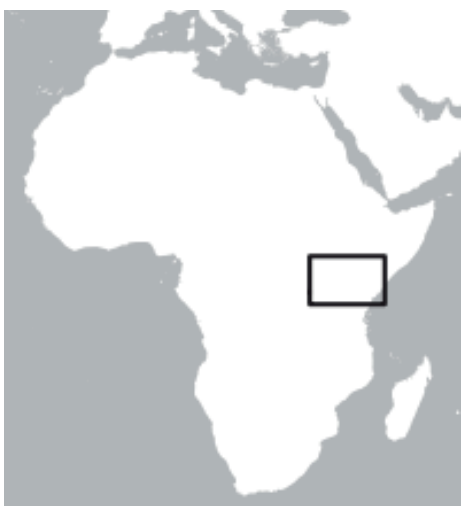

Map 2: Location of Research Area

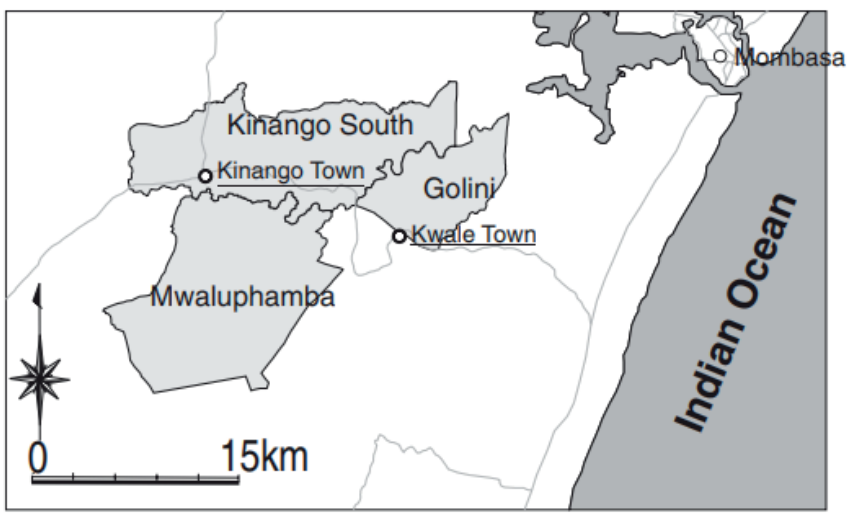

(Kaneko, et alii 2012, "Health and Demographic Surveillance System in the Western and Coastal Areas of Kenya: An Infrastructure for Epidemiologic Studies in Africa", Journal of Epidemiology: 22 (2012) Issue 3: 276-285.)

One use of this database for the purpose of this study was to extract limited target personnel, such as 'women over 60 years old in three areas, 10 each'. These women were the main interviewees, as well as their families. Additional interviews were carried out with the staff of the health facilities. The population of the target area was 27,470 males and 28,738 females in HDSS, and the population over 60 represented $5.45 \%$ of the total population, a ratio somewhat higher than that of Kenya overall (4.10\%). 
The research informants belonged to the Duruma and Digo ethnic groups. They were Muslim people and inter-marriages were common between these two groups. The research was conducted with the translators who were able to speak Duruma and Digo (as local languages) and English. We used two types of research methods: one was a qualitative study using semi-structed questionnaires on household and ageing issues in interviews; and one that used devices for checking quantitative information, like counting the steps and strength of activities for a week for 30 elderly women. In this paper, we focus on the results of the interviews.

All of the participants had children and grandchildren. Polygamy is common in the area, and husbands are normally older than their wives. Most of the time, elderly women take care of their husbands by cooking for them, washing their clothing, and performing other domestic tasks, but husbands do not take care of their wives. If an old woman lives in the same compound with her son's family, her son's wife may help her with domestic chores.

Daughters sometimes return to visit their parents and stay for a few days to help them. Most of the participants were healthy and energetic enough to cultivate a field, as well as to go to the market to sell vegetables and buy food. However, as they aged, it became difficult for them to walk long distances, and they preferred to stay at home.

Healthier women also played an important role in taking care of their grandchildren. As sons and daughters move to the cities to find work, the grandparents help with childrearing. Skip-generation households are common in this community. Seniors are happy to be with their grandchildren. Moreover, their children transfer money to their elderly parents. M-Pesa is one of the most popular systems for transferring money through mobile phones in Kenya. Compared with banks, which are few and far between in local areas, this system is very useful. Greatgrandmothers also act as caregivers to small children and babies.

However, once women themselves become sick or grow older, who takes care of them? In the case of husbands and fathers, younger wives and children can support them. Yet what about elderly mothers? According to 
the UNFPA report mentioned earlier, generally speaking, the situation is different for women compared to men, and women are more fragile in terms of economics and health. And what is the situation in rural areas in Kenya? In the case of women in households that are not wealthy, when older women become ill or have health problems, the research participants preferred to move to their sisters' or daughters' homes to be taken care of, and some of them had done this by the next visit.

The majority of the participants lived with family members who could take care of them and they did not have many urgent health problems. Some cases illustrate the current circumstances of ageing in society, whereby seniors require assistance from family members.

\section{Lives of Elderly Women in Rural Kwale}

Most of the old women live with family support; however, in terms of LTC, it seems more attention is necessary for some cases.

The landscape of Kwale area

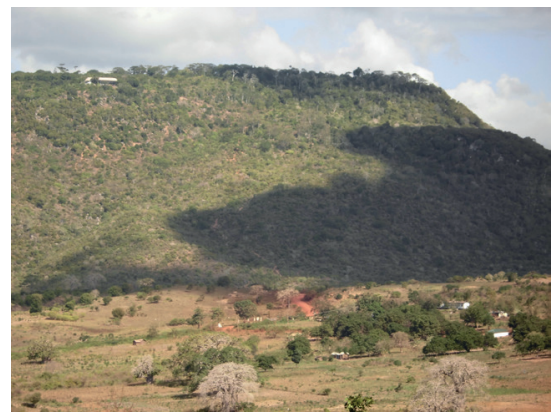

The house of an elderly woman

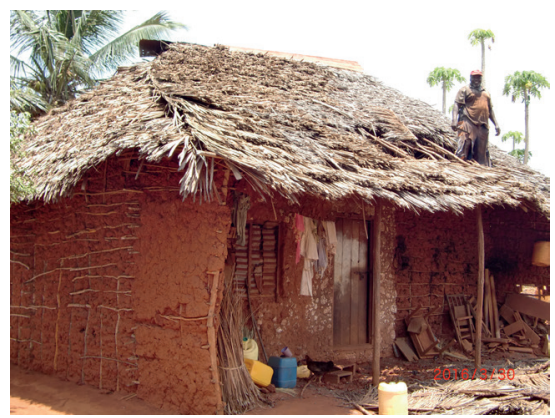




\section{Elderly women in a rural area}
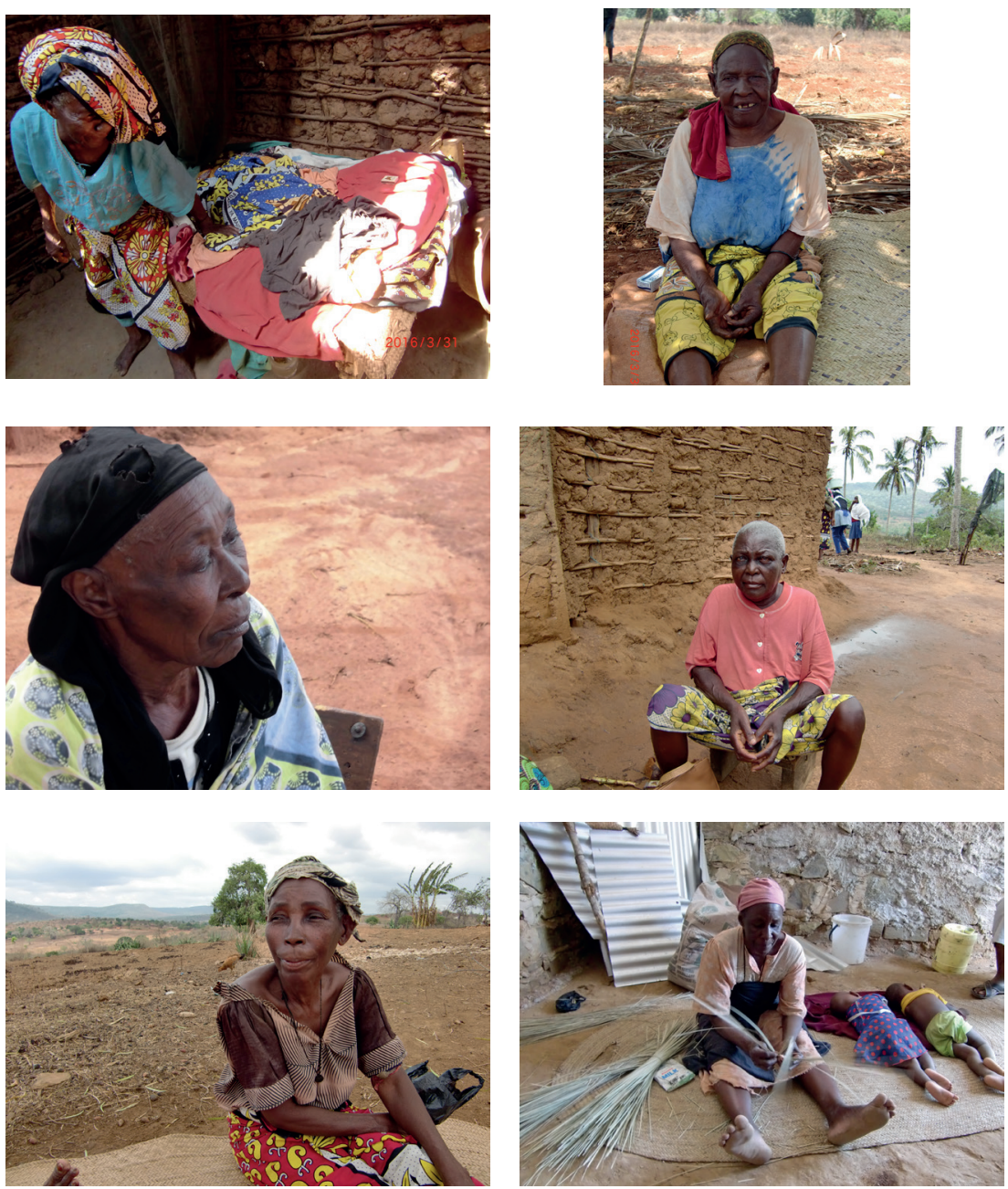

(Photos were taken by the authors in 2016) 


\section{a) Women Who Live Alone}

Urbanisation and globalisation have also affected senior citizens' lives in rural areas. Young people move to the cities to study and work, where they sometimes get married. They often do not return. Even though seniors may have many children, this does not mean that family members, especially children, can provide them with financial and physical support. Previously, when people were born in rural areas, they married there and had children and grandchildren. Housing compounds used to be full of several extended families. However, conditions are changing. We will present here two cases of participants who lived alone: A man passed away, leaving behind three wives, two of whom lived near the community in their husband's compound.

The first and second wives had very different situations. The second wife had four children, two sons, and two daughters. When we first visited the compound in 2016, she lived alone, and her children lived far from the community. The second wife said that her children did not come back often, maybe once a year or once every two years. She was 81 (this was in 2016) and worked in her field, cultivating maize and other crops, and taking care of livestock, such as goats and cows. She could manage her daily life, including cooking and washing. Nonetheless, she felt dizzy sometimes and suffered from memory loss. She felt lonely and often did not talk with anyone. Instead, she talked to her animals. When she needed money for medical fees or other matters, she called her children, who sent money to her. She did not have a mobile phone but borrowed one from her neighbour, whom her children also called in order to speak with their mother. During the two-week period in 2016 when we conducted our research, our research assistant visited this interviewee regularly. The second wife was always happy for the visit because no one visited her regularly and she loved to talk with other people.

In contrast, the first wife had 10 children (3 sons and 7 daughters), some of whom lived near the community. According to a daughter and son, who were at the interview, they had asked their mother to live with them. The first wife was 91 and unable to cook for herself. However, she refused to move and insisted on living alone in her husband's compound. 
Hence, the daughter and son made daily visits to bring her food. During the interview, the first wife was busy taking corn kernels of the cob. She said she preferred freedom and felt fine at home, even though she was alone. However, her children were worried about letting her stay home alone at night.

\section{b) Centenarian Women in Rural Areas}

Two participants were over 100 years old; one was very healthy and the other was bedridden. One was 102 in 2016, and still very healthy and energetic in 2018. Even though she felt pain in her knees and could not move easily, she was busy taking corn of the cob with firm hands during the interview, sitting on a small stool. Her grandson's wife helped her to wash. She said she liked to eat beef. The neighbours came and enjoyed chatting with her. One young mother who was chatting with her said, 'I always have a good time talking with her; she shares her wisdom. She is very funny. We are always laughing together.' The participant had been married twice, and her husbands had passed away long before. She had six children from her first husband. After his death, she married another man with whom she had six more children. She said, 'After the death of my second husband, I decided not to marry a third time because my son can take care of me. The husband was annoying. She lived in the house of her grandson, who was 56, and his wife. Among her 12 children, she had one daughter from whom she preferred to receive care, who regularly visited her mother. The participant could obtain OPCT, but because of the long distance and her health she could not go to the bank herself. Thus, her daughter was appointed as her guardian to withdraw money from the bank. Unfortunately, her daughter passed away in 2017. When I visited her in 2018, the participant mentioned that she could not withdraw money from the bank. She needed to go and re-register to appoint a new guardian who could withdraw money on her behalf. She relied on the pension of OPTC to cover food and medical costs, as well as personnel fees to pay farmers who cultivated her land and money to buy new plants as cash crops. In terms of health issues, she had a cataract on one eye. Her 
grandson helped her go to the eye clinic located near Kwale Town, where she had an operation. She recovered her eyesight after that.

Another participant was 100 years old at the time of the interview. According to her caregiver, her daughter-in-law (who herself was around 70 years old), she had memory loss. The daughter-in-law affirmed that the participant had been bedridden for 17 years. She had a good appetite but had to eat soft food, and her daughter-in-law had to feed her. The participant had 10 children (4 sons and 6 daughters). Her daughter-inlaw said, 'It is a huge burden to take care of my bedridden old motherin-law. I have pain in my back. I cannot go to the field to grow crops. My mother-in-law has many daughters, but they do not come to help. Usually, daughters take care of their parents'.

These cases show women's different health conditions. Even when women are elderly, they manage many things by themselves. However, once they become sick and bedridden, caregivers, mostly other women, take on the responsibility of caring for them without any information or training.

\section{c) Women with Eye Problems}

As noted above, if there is support for medical care, including transportation, old people can recover from illness. However, some cases demonstrate that medical support is not well-provided.

An elderly woman experienced pain in her left eye for several years. One of the medical doctors who accompanied my research mentioned that the problem seemed like onchocerciasis, commonly known as 'river blindness', caused by the parasitic worm Onchocerca volvulus, which is common in Africa. If the patient had been treated soon after contracting it at a clinic, she would not have lost her eyesight or had pain. She was suffering, but had no money to pay for medical fees or transport to the clinic. She was poor. Her son, who lived far from the rural area in which she lived, was unable to provide her with medical care.

Another participant had cataracts and had surgery in 2014. She was 90 in 2016, felt pain in her knees, and was nearly blind. However, she did not like to ride local forms of public transit, such as matatsu (small bus) 
because she would have to squeeze into a tight spot in order to sit down. She also said she did not have problems seeing, even though she clearly could not see well. She was a widow, and her eldest son took care of her. She felt happy to be surrounded by her grandchildren.

It seems that the problem the participants had visiting clinics involved finding someone to go with them, as well as someone to pay for their transportation and medical fees. There are several services for children and mothers in rural zones, but senior citizens receive little attention. If they have support, their quality of life will improve.

\section{d) Women Who Move to Other Houses}

It is common for women to move when they fall ill or grow older. When I visited the participants' homes, I met their sisters and their own mothers, who also needed care. When I asked why the participants had moved, one sister of an interviewee said, 'She does not feel comfortable staying by herself when she is sick. It is better for her to go to her sister's or daughter's home. I feel comfortable when my sister or daughter takes care of me'. Seldom do husbands cook or perform other domestic tasks. In the case of one interviewee, her sister had pneumonia and had already spent a few weeks at her home. The sister was almost recovering, and they were working together to make a mat of sisal to sell in the market.

Among the 30 women I interviewed in 2016, four moved to different homes in 2017. I will discuss two cases here: one participant who had diabetes, and another very old woman who moved several times.

When I visited the former participant for the first time, she had lost most of her eyesight due to diabetes. She received medication from Mombasa, which her son sent, but her condition was not good. She could manage to walk slowly, but was unable to perform domestic tasks or to work in the field. She was 66 years old and had two children (a son and a daughter) who had migrated for work. She was a widow and lived with two grandsons, aged 9 and 16, who helped her in her daily life. Her children sent her money, but it was not enough to live off. Due to poverty, the family could not buy vegetables, and they only ate ugali (maize) and chai. According to the participant, a doctor told her to stop eating sugar, 
but because of hunger, she put a lot of sugar in her chai; sugar was cheap and widely available in the community. This caused her even more serious health problems. When I visited her in 2017, according to her neighbour, she had moved to her daughter's home, because she had lost her eyesight and also had leg problems.

The second case is that of a small 90-year-old woman. She could walk slowly and eat soft food slowly. When I visited her in 2016 , she was living in her son's compound. She had five children (4 sons and I daughter), but her daughter had passed away. She was staying at her oldest son's compound. Her other sons lived close by, so there were many grandchildren in the compound. Yet when I visited her in 2017, I was told that she had moved to the hill. I tried to reach her and found her at her granddaughter's home. The granddaughter had married and moved to her husband's house, and they had children. According to the participant, she missed her daughter very much and decided to move to her granddaughter's home. She lived in a small kitchen hut, a very smoky place, but she said it was fine for her. When I visited in 2018, she had returned to a different son's compound, which was next to her previous house. Men do not usually move like this, they usually stay in their compounds; however, women move in order to take care of them.

\section{Key Findings}

Based on the suggestion of Cohen (2006), when considering the circumstances of ageing, both now and in the future, there are five points to consider with respect to ageing research in sub-Saharan Africa: 1) the household economy, 2) health and social welfare, 3) family support and networks, 4) public protections for old people, and 5) HIV/AIDS.

\section{1) The Household Economy}

People living in rural zones were primarily farmers and self-sufficient in terms of daily life. The economic level of Kwale County is lower than that of other areas. Some women run small businesses to produce and sell cash crops, make mats and bags from sisal, and sell dagaa (small fish) 
in the community, which they buy at the market. If they did not have an income, their children paid their medical fees and other costs.

Among the interviewees in 2016, four women received cash transfers. One used the money to pay for her grandchildren's school fees and for extra costs at home (she lived with her son's family). Many senior citizens applied for OPCT, but most of them failed and did not know why.

\section{2) Health and Social Welfare}

There are small public health facilities in rural communities called health dispensaries that provide general treatment. However, geriatrics, which includes preventive medical science for elderly people, is not common in Kenya. Thus, there is a tendency for seniors to receive less attention regarding their medication than small children. County-level and private hospitals also offer several services, but seniors primarily depend on their family members.

Except for OPCT, there seemed to be no social welfare for LTC. Families were expected to care for elderly individuals who were ill or bedridden. Women provided the majority of care work and often received no support. There was no information and training for LTC, which caused physical problems for caregivers. Caregivers who support old women also tended to be old, sometimes 60 to7o years old. Unlike in the capital, Nairobi, there were no private medical services or non-governmental organisations (NGOs) for seniors in rural zones.

\section{3) Family Support and Networks}

Most Kenyans believe that families should care for their old parents. This was comparatively true among the participants, but in some cases, depending on the family, the situation was different. In Nairobi, many old women live alone and are vulnerable to being robbed. In Kwale, as well as other rural areas, sons build homes in their parents' compounds, but some cases shows that they did not live there, therefore when this happened, they could not provide their parents with physical support. If seniors lived with their school-age grandchildren, the so called 'skip generation', their grandchildren could help them. 
To date, in rural regions, no women have been abandoned. However, the quality and quantity of 'help' differs across families. Family structures today also differ from the traditional Kenyan lifestyle; thus, care for seniors will need more social support. In cities like Nairobi, there are networks that advocate for elderly people, but there are no such institutions in rural parts of the country.

\section{4) Public Protections for Elderly People}

As noted above, most people applied for the OPCT but failed to qualify for it (in the research in 2017). A participant said, 'If I could receive a cash transfer, I would eat a lot of mandazi [fried donuts] and buy goats'. OPCT was launched in three other counties first, then expanded to additional areas, but it served a limited number of people. In 2018, it became unconditional for those over 70 . However, obtaining it requires going through a long process. Unlike European countries and Japan, there are no specific policies in African nations to provide other public protections for seniors.

\section{5) HIV/AIDS}

Kenya has a high prevalence of HIV/AIDS. In Kwale, the HIV rate was 5.7\% in 2014, and Kenya was ranked as a medium-epidemic county. Two of the participants' households had orphans whose parents had died from HIV/ AIDS. Their grandparents were their guardians. One grandmother told me that it was not a burden for her to take care of her grandchildren, and she felt happy staying with them. Her daughter and the daughter's husband had passed away because of HIV/AIDS, and her other children could pay for the grandchildren's school fees. There was a government plan to support orphans whose parents died from HIV/AIDS, which involved a cash transfer. However, the grandmother I interviewed did not apply for it because the procedures seemed too cumbersome to complete, and she was illiterate. For older women, it was difficult to obtain information and to apply for such support in general. 


\section{Conclusions}

This was a preliminary study for collaboration with other interdisciplinary fields based on HDSS in the near future. The objective was to provide an overview of the current situation of elderly women's lives in rural Kenya before starting a research project in Kwale. We obtained several findings related to LTC perspectives in rural parts of Kenya. First, caregivers of older women were mostly other women, such as daughters or daughtersin-law. Women moved (sometimes unwillingly) to different homes to care for family members. Second, certain social changes had led old women to live alone, and they sometimes lacked support from their own children. Kenya currently has a social problem whereby old women live alone, even in cities. Women live longer than men, according to national statics; however, children's support and responsibilities seem to be shifting. Third, there was insufficient medical support. Some individuals were bedridden and had health problems. Moreover, seniors did not receive enough attention from public health experts.

This study has the limitation that we only interviewed a small number of women and no old men, in a limited area covering three locations in Kwale County. However, there have been few previous ethnographies or writings on women and care, therefore it contributes to increasing the information on the ageing and care situation for elderly people in rural areas of Kenya.

\section{Acknowledgements}

The research was carried out with a lot of support from local people and medical staff in Kwale, we greatly appreciate their assistance. Financially, it was funded by several grants, including the Japan Society for the Promotion of Science (JSPS) KAKENHI, Grants-in-Aid for Scientific Research, 'Anthropological Research on Care for Elderly Women in Africa' (No. 18K11899) and 'Future Population Ageing in East Africa: A CrossDisciplinary Study of Social Welfare and Elderly Care' (PL: Prof. Ken Masuda; No. 18H03604). 


\section{References}

ABODERIN, I. (2006) Intergenerational Support and Old Age in Africa. New York: Routledge.

Abubakar A., Van Baar A., Fischer R., Bomu G, Gona JK, Newton CR (2013) "Socio-Cultural Determinants of Health-Seeking Behaviour on the Kenyan Coast: A Qualitative Study". PLoS ONE. 8(11): e71998.

Bennetta, R. (2016) "Gender Differentials and Old Age Survival in the Nairobi Slums, Kenya" Social Science \& Medicine. 163, August 2016: 107116.

Buch, E. D. (2015) "Anthropology of Aging and Care", Annual Review of Anthropology. 44:277-93.

Cohen, B. \& Menken, J. (eds.) (2006) Aging in Sub-Saharan Africa: Recommendation for Furthering Research. Washington: The National Academic Press.

De Medeiros, K. (2013) Narrative Gerontology in Research and Practice. New York: Springer Publishing Company.

Fry, C. L. (2000) "Social Anthropology and Gerontology", DANnEFER, D. \& Phillipson, C. (eds.) The SAGE Handbook of Social Gerontology, Los Angeles: SAGE.

Habte-Gabr, E. et alii (1987) "The Elderly in Africa", The Journal of Applied Gerontology, 6(2): 163-182.

Ikiara, G. (2009) The Political Economy of Cash Transfers in Kenya: A Report Prepared for the Overseas Development Institute. Overseas Development Institute.

Kaneko, S. (2012) "Health and Demographic Surveillance System in the Western and Costal Areas of Kenya: An Infrastructure for Epidemiologic Studies in Africa", Journal of Epidemiology, 22 (3): 276285.

MASUDA, K. (2009) "Situating the Banna: An Ethnographic Description of Ethnic Identification." Nailo-Ethiopian Studies, 13: 47-62.

Matsuda, M. (2000) "Social Welfare in Western Kenya", WazAKi, H. ed., Social Welfare in the World: Africa, Middle and South America, and Spain (vol.11), 17-39, Junpousya. (in Japanese) 
McIntosh, J. (2009) “Elders and 'Frauds': Commodified Expertise and Politicized Authenticity among Mijikenda”, Africa, 79(1):35-52.

Miyachi, K. (2014) "Cultural Transformation: Sociocultural Aspects of Female Circumcision among the Gusii People in Kenya", Nilo-Ethiopian Studies, 19: 1-5.

Miyachi, K. (2017) “Consideration towards the Care for the Elderly Women in Rural Kenya”, Community Caring, 19(13): 76-81. (in Japanese)

Mochache, V., Wanje, G., Nyagah, L. et alii (2020) "Religious, socio-cultural norms and gender stereotypes influence uptake and utilization of maternal health services among the Digo community in Kwale, Kenya: a qualitative study". Reproductive Health, 17(71): 1-10.

Mudege, N. et alii (2009) "Gender, Aging, Poverty and Health: Survival Strategies of Older Men and Women in Nairobi Slums", Journal of Aging Studies, Dec; 23(4): 245-257.

Noguchi, M. (2013) "Aging among the Aari in Rural Southwestern Ethiopia: Livelihood and Daily Interactions of the 'galta", African Study Monograph Supplementary, 46: 135-154.

Republic of Kenya (2014) National Policy on Older Person and Aging. Ministry of Labour Social Security and Services.

Sheru, W. et alii (2013) "Profile: The Mbita Health and Demographic Surveillance System”, International Journal of Epidemiology, 42:16781685.

TAGAWA, G., et alii (ed.) (2016) The Elderly in Africa: The Ethnographies of System of Aging and Power Relation. Fukuoka. Kyushudaigakusyuppankai. (in Japanese)

UN (2002) Political Declaration and Madrid International Plan of Action on Ageing (Second World Assembly on Ageing, Madrid, Spain). NY: UN.

UNFPA (2012) Ageing in the Twenty-First Century: A Celebration and A Challenge. UNFPA.

Ungerson, C., (1987) Policy Is Personal: Sex, Gender, and Informal Care. New York: Tavistock.

WHO (2015) World Report on Ageing and Health 2015. WHO.

WHO (2017) Towards Long-Term Care Systems in sub-Saharan Africa. WHO. 


\section{Internet Information}

World BANK GRoup (IBRD) Data in Kenya: <https://data.worldbank.org/ indicator/SP.POP.TOTL?locations=KE\&view=chart $>$ (03/09/2017 Access)

Atsuga, I. 2017 “The Social Welfare and Old Age (over 70 years old) Pension for all in Kenya: <https://www.povertist.com/ja/universal-pensionin-kenya/> (03/09/2017 Access)

HelpAge International (African Region): <https://www.helpage.org/ where-we-work/africa/> (27/09/2016 Access)

Kenya National Bureau of Statistics \& Society for International Development, 2013 "Exploring Kenya's Inequality: Pulling Apart or Pooling Together?" (Kwale County): <http://www.inequalities. sidint.net/kenya/wp-content/uploads/sites/2/2013/09/Kwale.pdf> (01/09/2019 Access)

The Global Ageing Study Group (GASG): <http://global-ageing.org/> (01/02/2019 Access) 